\title{
EVALUATION OF Trichoderma spp. AND Clonostachys spp. STRAINS TO CONTROL F usarium circinatum IN Pinus radiata SEEDLINGS
}

\author{
Priscila Moraga-Suazo ${ }^{1}$, Alex Opazo ${ }^{1}$, Salomé Zaldúa1, Gastón González ${ }^{2}$, and Eugenio Sanfuentes ${ }^{1 *}$
}

The fungus Fusarium circinatum Nirenberg \& O'Donnell causes pine pitch canker, an important disease for conifers worldwide. F. circinatum was first detected in Chile in 2001 and to date is present in nurseries and clonal hedges from Libertador General Bernardo O’Higgins Region to Los Ríos Region. The purpose of this study was to evaluate the potential of Trichoderma spp. and Clonostachys spp. strains to control F. circinatum in Pinus radiata D. Don seedlings in the absence of other effective control methods. Eighty-one Trichoderma spp. and Clonostachys spp. strains were evaluated through in vitro assays to determine their ability to act as antagonists of $F$. circinatum and 21 strains were tested for their ability to reduce post-emergence mortality and increase $P$. radiata survival under greenhouse conditions. During in vitro experiments, 15 strains of Trichoderma inhibited mycelial growth of the pathogen by more than $60 \%$ and one strain of Clonostachys showed parasitism of $F$. circinatum hyphae. Greenhouse experiments showed no control of the disease when the antagonists were added to substrate after the pathogen. However, when the antagonists were added before the pathogen, four strains (Clonostachys UDC-32 and UDC-222 and Trichoderma UDC-23 and UDC-408) reduced post-emergence mortality between 80 and $100 \%$. Among these strains, only Clonostachys UDC-222 significantly increased the survival of $P$. radiata seedlings. These results showed that Clonostachys UDC-222 has the potential to be used as a biocontrol agent against $F$. circinatum in the production of $P$. radiata plants.

Key words: Antagonists, biological control, seedling death, pitch canker.

$F$ usarium circinatum Nirenberg \& O'Donnell is a necrotrophic fungus that causes pitch canker disease, which affects pine species (Coutinho et al., 2007; Wingfield et al., 2008; Quesada et al., 2010) and Pseudotsuga menziesii (Gordon et al., 2006). Among the affected pine species, Pinus radiata D. Don is considered one of the most susceptible to this pathogen (Gordon et al., 2001).

Pine pitch canker was first detected in south-eastern United States and then in Mexico (Schweigkofler et al., 2004), where it likely originated (Wikler and Gordon, 2000). More recently, this disease has been reported in California, South Africa, Haiti, Japan, and Spain (Storer et al., 2002). In Chile, the presence of the pathogen was reported in late 2001 at $P$. radiata nurseries located between Libertador General Bernardo O'Higgins Region and Los Ríos Region, but rarely in 1 to 4-yr-old plantations, where secondary dissemination has not been reported (Wingfield et al., 2002). The behavior of the disease in Chile is similar to that observed in South Africa with $P$. patula Schltdl. \& Cham., where the pathogen mostly attacked nursery seedlings and was not associated

${ }^{1}$ Universidad de Concepción, Facultad de Ciencias Forestales, Casilla 160-C, Concepción, Chile.

"Corresponding author (esanfuen@udec.cl).

${ }^{2}$ BIOCAF S.A., km 18 Camino a Coronel, Chile.

Received: 21 January 2011.

Accepted: 7 June 2011. with pitch canker, the typical symptom in plantations. However, the first outbreaks of pitch canker in $P$. patula plantations have recently been reported in South Africa (Coutinho et al., 2007). The absence of field infections in Chile has been attributed to the low frequency of insect vectors, unfavorable climatic conditions for the disease development (Wingfield et al., 2002), and low inoculum concentration in the environment.

The practices used to control this disease in Chilean forestry nurseries include cultural measures, such as early detection of symptoms and signs of $F$. circinatum and removal of diseased seedlings, environmental management, pathogen population monitoring in nursery soil and bark substrate, container sterilization, pathogen spread prevention to uninfected areas, and detection of asymptomatic seedlings (González, 2005; Rotella, 2005).

Among the fungicides used to control $F$. circinatum are prochloraz, tebuconazole, and propamocarb (TPCP, 2002). In studies conducted by Mitchell et al. (2005), the first two fungicides were the most effective. In Chile, difenoconazole, tebuconazole, and fludioxinil inhibited mycelial growth of the pathogen during in vitro tests (González, 2005). Nevertheless, little is known about the most suitable fungicides for controlling $F$. circinatum.

Due to more stringent environmental restrictions on fungicides, the search for alternative methods of disease control has increased, such as biological control. The use of microorganisms, individually or in combination 
with other measures, that reduce the use of pesticides has become increasingly important. Antagonistic microorganisms, including fungi and bacteria, applied as treatments for seeds provide unique and beneficial opportunities for the production of different crops, especially protection against soil-borne pathogenic fungi (Mao et al., 1997).

Several studies have used fungi and bacteria to control diseases caused by Fusarium species affecting different crops (Mao et al., 1997; Mao et al., 1998; Bacon et al., 2001), including some non-pathogenic strains of Fusarium spp. (Paulitz et al., 1987; Postma and Rattink., 1992; Larkin and Fravel, 2002; Silva and Bettiol, 2005). Nonetheless, few studies have been done on biological control of $F$. circinatum, among them the use of Trichoderma harzianum strains to control the disease in P. patula seedlings (Mitchell et al., 2005).

Despite the importance of the disease, no effective methods for its control have been found, no chemical products have been registered and no biological agents are being marketed. This limits disease management options in affected nurseries. Due to current and potential damage arising from the presence of $F$. circinatum, the secondary dissemination risk in plantations and the lack of efficient control methods, the objective of this study was to select and evaluate strains of Trichoderma spp. and Clonostachys spp. for the control of $F$. circinatum in $P$. radiata seedlings.

\section{MATERIALS AND METHODS}

\section{Antagonists and pathogen strains}

Strains of Trichoderma (71 strains) and Clonostachys (10 strains) were selected for the assays from the Forest Pathology Laboratory collection from the Universidad de Concepción. These strains have shown activity as antagonists against other pathogens in previous studies (Grandón, 2006; Mellado, 2006; Molina et al., 2006). One F. circinatum strain (Pr44-4641) was also included, isolated from symptomatic $P$. radiata hedges that had more aggressive behavior in previous pathogenicity tests (González, 2005). Antagonistic fungi and pathogens were stored in tubes containing potato dextrose agar (PDA) as culture medium at $4{ }^{\circ} \mathrm{C}$. Fungal strains were replicated in Petri dishes containing PDA and incubated at $25^{\circ} \mathrm{C}$ for $4 \mathrm{~d}$ (Trichoderma) and $7 \mathrm{~d}$ (Clonostachys and F. circinatum).

\section{In vitro antagonistic activity}

For the in vitro antagonism test, a modified version of the dual culture technique described by Bell et al. (1982) was used. A $6 \mathrm{~mm}$ diameter plug, containing expanding colonies of $F$. circinatum, was removed from the edge of actively growing culture and placed approximately $1 \mathrm{~cm}$ from the edge of a Petri dish containing PDA diluted to $50 \%$. Similarly, using the antagonist strains available, a 6 $\mathrm{mm}$ diameter round plug was removed from the actively growing culture and placed directly opposite to the $F$. circinatum sample, approximately $1 \mathrm{~cm}$ from the edge of the Petri dish. As control, a $6 \mathrm{~mm}$ diameter plug of $F$. circinatum strain was placed onto a separate Petri dish to compare their uninhibited growth with paired cultures. The paired cultures were incubated at $25{ }^{\circ} \mathrm{C}$ for $7 \mathrm{~d}$ before being assessed. The pathogen plug was inoculated $24 \mathrm{~h}$ before the antagonist plug on each Petri dish. After the assay, the mycelial growth inhibition (MGI) of $F$. circinatum was determined along with the presence of parasitism in the pathogen hyphal.

The MGI was obtained by dividing the pathogen colony area into different dual cultures facing the antagonists by the pathogen colony area from the control treatment. Colony surface areas were measured with a dot grid of 0.5 $\times 0.5 \mathrm{~cm}$.

Parasitism was determined under microscope observation at 100X and 400X, observing the interaction area between colonies confronting each other in the dual cultures. The occurrence of coiled hyphae was considered to be evidence of hyphal parasitism. When no interactions were clearly observed among hyphae, new pairings were made on slides coated with a thin film of agar-water (AW) and incubated at $25^{\circ} \mathrm{C}$ for 2 to $3 \mathrm{~d}$.

\section{Control of $F$. circinatum in $P$. radiata seedlings}

Eighteen strains of Trichoderma and three of Clonostachys were used for this study. These strains were selected during an earlier in vitro antagonism test; since they showed either higher pathogen mycelial inhibition or hyphal parasitism, and some of these selected strains have also been used to control other pathogens such as Macrophomina phaseolina and Botrytis cinerea (Grandón, 2006; Molina et al., 2006). The experiments were performed in the greenhouse propriety $\mathrm{CPF}$ (Controladora de Plagas Forestales) and authorized by the government agency Servicio Agrícola y Ganadero (SAG) for quarantine tests with $F$. circinatum.

Pinus radiata seeds provided by Forestal Mininco S.A, previously surface disinfected for 15 min with hydrogen peroxide, were sown in trays containing pine bark compost previously sterilized by autoclaving twice at $121^{\circ} \mathrm{C}$ for 30 min, with an interval of $24 \mathrm{~h}$. Two assays were established simultaneously: in the first assay, the antagonists were applied $7 \mathrm{~d}$ before $F$. circinatum inoculation, and in the second assay, the pathogen was inoculated $48 \mathrm{~h}$ before antagonists. The substrate was sprayed with separate suspensions containing each antagonist $\left(10^{7}\right.$ to $10^{8}$ conidia $\left.\mathrm{mL}^{-1}\right)$ and pathogen $\left(10^{3}\right.$ conidia $\left.\mathrm{mL}^{-1}\right)$ in sterile distilled water.

Two comparative treatments were used in both assays. In the first treatment, only the pathogen was applied and in the second one, only water was applied as a control. The assays were maintained for $60 \mathrm{~d}$ after seedling emergence and two variables were evaluated, post-emergence mortality and seedling survival. 
Post-emergence mortality was defined as those seedlings having the symptoms described for dampingoff. The post-emergence mortality rate was obtained by dividing the number of dead seedlings by the total seedlings emerged (\%). Emerged seedlings were considered as those with cotyledons above the substrate surface. All dead seedlings were collected, surface disinfected with sodium hypochlorite $(5 \% \mathrm{v} / \mathrm{v})$ for $3 \mathrm{~min}$, and then transferred to Petri dishes with PDA medium to determine infection by $F$. circinatum.

The seedling survival rate was obtained by dividing the number of symptom-free $P$. radiata seedlings at the end of the assay by the number of seeds sown (\%).

\section{Experimental design and data analysis}

The in vitro studies used a completely randomized design with four replicates for each strain plus a control (F. circinatum only). The experimental unit consisted of one Petri dish. Greenhouse experiments also used a completely randomized design with four replicates, and the experimental unit was composed of five plastic containers with one seedling each.

Statistical data analysis was performed by ANOVA with a significance level of 0.05 . All the data were subjected to analysis of homogeneity of variance and normality assumptions and pooled accordingly. Multiple comparisons were made using the Tukey test. Analyses were performed with Statistical Analysis System sofware (SAS Institute, 2000).

\section{RESULTS AND DISCUSSION}

\section{In vitro antagonistic activity}

The in vitro assays showed mainly an inhibitory effect of the antagonistic strains on the growth of $F$. circinatum colony (Figure 1). Many of the Trichoderma strains colonized a large area of the culture medium in the plates due to the speed of their mycelial growth, which was higher than that of $F$. circinatum. On the contrary, Clonostachys strains normally had slower growth rates than the pathogen. Furthermore, it was also noted that several Trichoderma strains sporulated abundantly when growing over the pathogenic colony, thereby indicating that they can be highly competitive for space and nutrients (Figure 1B). Only Clonostachys UDC-222 (Figure 1C) was capable of parasitizing $F$. circinatum hyphae (Figures $2 \mathrm{~A}$ and $2 \mathrm{~B}$ ). None of the tested strains showed antagonism by antibiosis.

From the 81 strains assayed in vitro, 76 significantly reduced $F$. circinatum mycelial growth. Of these, 49 inhibited the pathogen by 40 to $60 \%$ and 15 by 60 to $68 \%$. All strains inhibiting the mycelial growth belonged to the genus Trichoderma. Strains of Clonostachys showed lower levels of pathogen inhibition (1-23\%), among them Clonostachys UDC-A32 had the highest value (Figure 3).

These results are consistent with previous studies

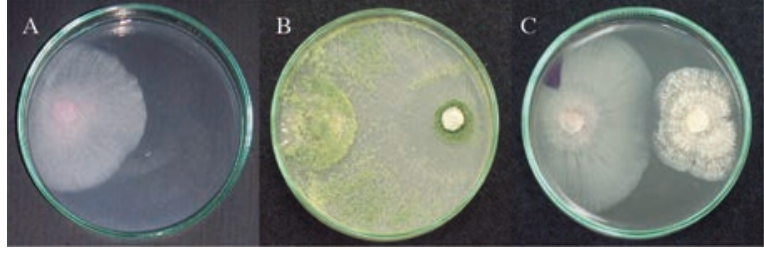

Figure 1. In vitro assays to detect antagonistic activity of fungal strains against Fusarium circinatum. (A) Control (only F. circinatum). (B) Trichoderma UDC-412 (right) with a marked inhibition of the mycelial growth of the pathogen (left). (C) Clonostachys rosea UDC-222 (right), which showed hyphal parasitism on $F$. circinatum (left).

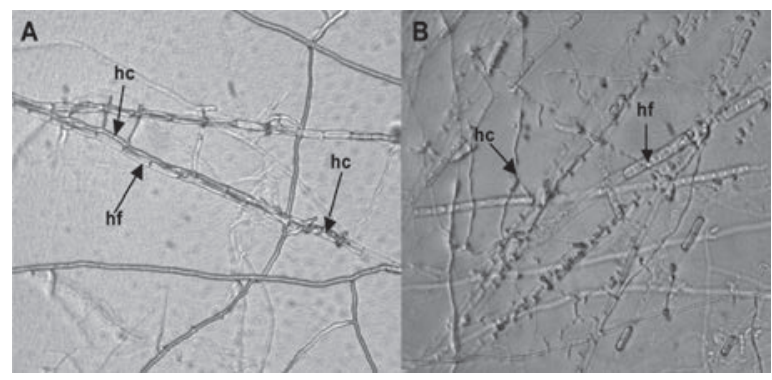

Figure 2. Signs of parasitism of Clonostachys UDC-222 (hc) on Fusarium circinatum hyphae (hf). Antagonistic hyphae growing along with $F$. circinatum hyphae, where coiling points were observed (A). Hyphae of the pathogen showing numerous points of contact with hyphae of the antagonist (B).

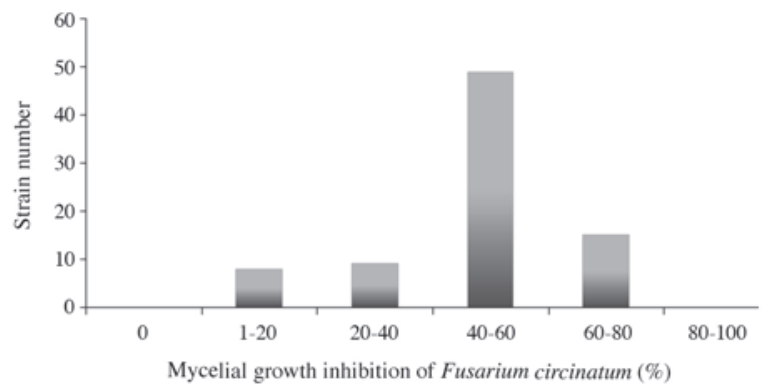

Figure 3. In vitro inhibition of the mycelial growth of Fusarium circinatum obtained by the antagonistic strains.

in which Trichoderma strains have been reported to be agents that inhibit pathogen growth as a biocontrol mechanism (Benítez et al., 2004; Vinale et al., 2008). In this study, the main mechanism of antagonism detected was space and nutrients competition, expressed as MGI. This mechanism, used by Trichoderma spp., has also been found against other Fusarium species such as $F$. solani and $F$. oxysporum (Herrera, 2005). In a study with $F$. circinatum, a strain of $T$. harzianum was observed to grow rapidly on the culture medium, restricting the growth of the pathogen and even causing the collapse of the hyphae after $7 \mathrm{~d}$ (Mitchell et al., 2005).

Parasitism of the hyphae was found to be the form of antagonism used in the case of Clonostachys UDC-222, identified as Clonostachys rosea. The ability of $C$. rosea for mycoparasitism of hyphae, sclerotia, and other fruiting bodies in various types of fungi is well known (Sutton et al., 1997). The species also produces fungal inhibitors and 
enzymes (glucanases) that degrade cell walls, inducing the loss of turgor and causing lysis of pathogenic hyphae (Papavizas, 1985; Sutton et al., 1997).

\section{Control of $\boldsymbol{F}$. circinatum in $P$. radiata seedlings}

When the pathogen was added to substrate $48 \mathrm{~h}$ before antagonists, none of the variables evaluated differed significantly between treatments, with post-emergence mortality of seedlings ranging from $25 \%$ to $100 \%$. Only three Trichoderma strains (UDC-280, UDC-351, UDC-404) showed less than 50\% seedlings mortality. However, these had low survival, indicating that much of the mortality occurred before the seedlings emerged. In the control treatment (without the application of the pathogen), the post-emergence mortality was high (89\%). This was attributed to the presence of the inoculant in the greenhouse environment, which allowed the pathogen to colonize the treatment, mainly targeting the aerial parts of plants through the cotyledons (data not shown).

When the antagonists were added to the substrate before adding the pathogen, significant differences were observed in post-emergence mortality and seedling survival (Figures 4 and 5). The application of Trichoderma strains UDC-23 and UDC-408 significantly reduced post-emergence mortality, with values of $8.3 \%$ and $0 \%$, respectively, compared to $94 \%$ mortality obtained when applying $F$. circinatum only. On the other hand, Clonostachys strains UDC-A32 and UDC-222

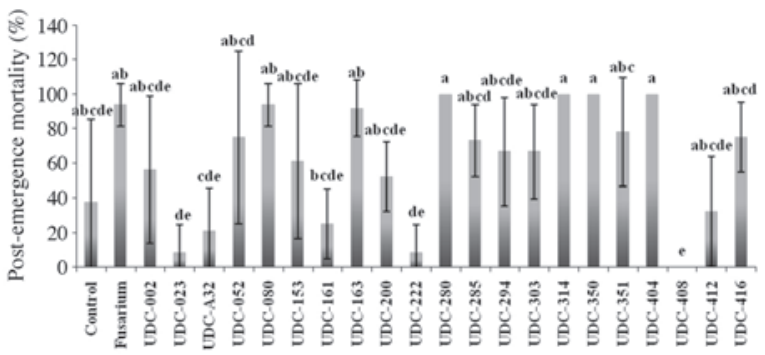

Different letters indicate significant differences according to Tukey Test, $\alpha=0.05$.

Figure 4. Effect on the post-emergence mortality (\%) of Pinus radiata seedlings of incorporating the antagonists to the substrate prior to the application of Fusarium circinatum.

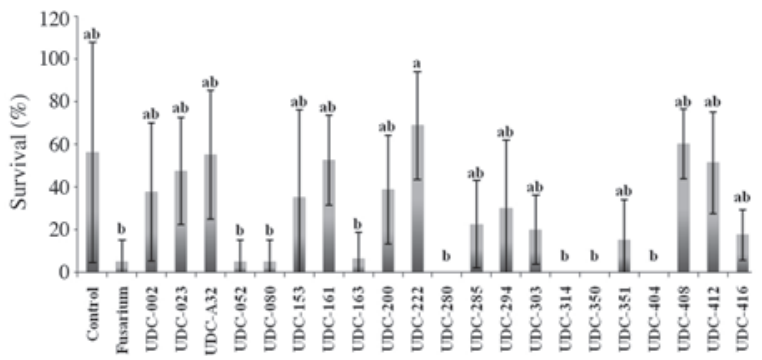

Different letters indicate significant differences according to Tukey Test, $\alpha=0.05$.

Figure 5. Effect on the survival (\%) of Pinus radiata seedlings of incorporating the antagonists to the substrate prior to the application of Fusarium circinatum. reduced post-emergence mortality to $20.8 \%$ and $8.3 \%$, respectively (Figure 4).

Regarding the survival of seedlings, the four strains able to reduce post-emergence mortality were the same ones that had the highest values of seedling survival. However, a significant increase was achieved in this variable (69\%) by applying $C$. rosea UDC-222. Treatments in which only the pathogen was added had seedling survival rates of about 5\% (Figure 5).

The performance of $C$. rosea $\mathrm{UDC}-222$ in reducing post-emergence mortality and increasing seedling survival indicates that this fungus is able to protect seedlings from the beginning of the development of (pre-emergence stage), producing a protective effect on the seed. The better capacity of $C$. rosea UDC-222 to act as a biocontrol agent could be explained in part by its use of two forms of antagonism: competition for space and nutrients and, more importantly, parasitism of the hyphae. Considering that both the pathogen and the antagonist presented similar growth rates, this form of antagonism collapsed pathogenic hyphae, removing it from the substrate and previously colonized tissues (Sutton et al., 1997).

Another hypothesis that could explain the success of this strain is its ability to colonize. Some Clonostachys strains are known to act as non-pathogenic endophytes, colonizing host tissues without causing alterations in the plant and thereby eliminating the potential development and sporulation of pathogenic fungal agents (Sutton et al., 2002). In this case, $C$. rosea UDC-222 could have colonized some seedling tissues before the arrival of the pathogen, allowing a reduction in the incidence of the disease.

This study has demonstrated the importance of timing in the application of biocontrol agents: good results were obtained only when the antagonists were previously incorporated in the substrate. This strategy was also demonstrated in studies with raspberries, where $C$. rosea suppressed sporulation and interfered with infection and colonization of $B$. cinerea most effectively when applied before or when the pathogen was introduced (Yu and Sutton, 1997).

\section{CONCLUSION}

These results indicate that $C$. rosea UDC-222 has the ability to reduce the incidence of $F$. circinatum in $P$. radiata seedlings, establishing the potential use of antagonists for the control of this pathogen in forestry nurseries. However, initial results indicate that control is only possible before the pathogen reaches the substrate.

\section{ACKNOWLEDGEMENTS}

The authors acknowledge the SAG-funded project "Fusarium circinatum Nirenberg \& O'Donnell: Conocimiento del patógeno y establecimiento de bases 
para su control en Pinus radiata", and the CPF for facilitating the greenhouses authorized for work with $F$. circinatum. Evaluación de cepas de Trichoderma spp. y
Clonostachys spp. para controlar Fusarium circinatum
en plántulas de Pinus radiata. Fusarium circinatum Nirenberg \& O’Donnell es el hongo que causa el cancro resinoso del pino, una enfermedad de importancia mundial en coníferas. En Chile, F. cicirnatum fue detectado por primera vez el año 2001 y a la fecha se encuentra presente en algunos viveros y huertos clonales desde la Región del Libertador General Bernardo O’Higgins hasta la Región de Los Ríos. Debido a la ausencia de métodos eficientes para controlar este patógeno, el propósito de este estudio fue evaluar el potencial uso de cepas de Trichoderma y Clonostachys como control de $F$. circinatum en plántulas de Pinus radiata D. Don. Ochenta y un cepas de Trichoderma spp. y Clonostachys spp. fueron evaluadas a través de ensayos in vitro para determinar su habilidad para actuar como antagonistas de $F$. circinatum y 21 cepas fueron probadas por su habilidad para reducir la mortalidad post-emergencia e incrementar la supervivencia de $P$. radiata bajo condiciones de invernadero. Durante los experimentos in vitro, 15 cepas de Trichoderma inhibieron el crecimiento del patógeno más de un $60 \%$ y una cepa de Clonostachys mostró parasitismo de hifas de $F$. circinatum. En experimentos en invernadero, los antagonistas no controlaron la enfermedad cuando fueron agregados después de la inoculación del patógeno. Sin embargo, cuando los antagonistas fueron sembrados antes del patógeno, cuatro cepas (Clonostachys UDC-32 y UDC-222, Trichoderma UDC-23 y UDC-408) redujeron la mortalidad post-emergencia entre 80 y $100 \%$. Entre estas cepas, sólo Clonostachys UDC-222 incrementó significativamente la supervivencia de plántulas de $P$. radiata. Estos resultados demuestran que Clonostachys UDC-222 posee gran potencial para ser empleado como agente de biocontrol contra $F$. circinatum en la producción de plantas de $P$. radiata.

Palabras clave: antagonistas, control biológico, muerte de plántulas, pitch canker.

\section{LITERATURE CITED}

Bacon, J., I. Yates, D. Hinton, and M. Filmore. 2001. Biological control of Fusarium moniliforme in maize. Environmental Health Perspectives 109:325-332.

Bell, D., H. Wells, and C. Marham. 1982. In vitro antagonism of Trichoderma species against six fungal plant pathogens. Phytopathology 72:379-382.

Benítez, T., A. Rincón, M. Limón, and A. Codón. 2004. Biocontrol mechanisms of Trichoderma strains. International Microbiology 7(4):249-260.

Coutinho, T., E. Steenkamp, K. Mongwaketzi, M. Wilmot, and M. Wingfield. 2007. First outbreak of pitch canker in South African pine plantation. Australasian Plant Pathology 36:256-261.

González, G. 2005. Resultados preliminares del estudio Fusarium circinatum: conocimiento del patógeno y establecimiento de bases para su control. In Resúmenes de la XX Silvotecna: Sanidad forestal en un mundo globalizado. Sesión $N^{\circ}$ 13. 7-8 November 2005. CORMA Bío Bío, Concepción, Chile.

Gordon, T.R., S.C. Kirkpatrick, B.J. Aegerter, D.L. Wood, and A.J. Storer. 2006. Susceptibility of Douglas fir (Pseudotsuga menziesii) to pitch canker, caused by Gibberella circinata. Plant Pathology 55:231-237.

Gordon, T.R., A.J. Storer, and D.J. Wood. 2001. The pitch canker epidemic in California. Plant Disease 85:1128-39.

Grandón, G. 2006. Selección in vitro de hongos antagonistas a Macrophomina phaseolina (Tassi) Goid. Tesis Ingeniero Forestal. Universidad de Concepción, Facultad de Ciencias Forestales, Concepción, Chile.

Herrera, R. 2005. Control biológico de Rhizoctonia solani, Fusarium oxysporum $f$. sp. lycopersici y Fusarium solani en tomates bajo invernaderos. Universidad de Chile Facultad de Ciencias Agronómicas, Santiago, Chile. Available at http://mazinger.sisib. uchile.cl/repositorio/lb/ciencias_agronomicas/montealegre_j/14 html (accessed 16 September 2009).

Larkin, R., and D. Fravel. 2002. Effects of varying environmental conditions on biological control of Fusarium wilt of tomato by nonpathogenic Fusarium spp. Phytopathology 92:1160-1166.

Mao, W., J. Lewis, P. Hebber, and R. Lumsden. 1997. Seed treatment with a fungal or a bacterial antagonist for reducing corn dampingoff caused by species of Pythium and Fusarium. Plant Disease 81:450-454.

Mao, W., R.D. Lumsden, J.A. Lewis, and P.K. Hebbar. 1998. Seed treatment using pre-infiltration and biocontrol agents to reduce damping off corn caused by species of Pythium and Fusarium. Plant Disease 83:294-299.

Mellado, C. 2006. Control biológico de la pudrición carbonosa de la raíz (Macrophomina phaseolina (Tassi) Goid). en viveros forestales mediante hongos antagonistas. Tesis Magister en Ciencias, mención Microbiología. Universidad de Concepción, Facultad de Ciencias Biológicas, Concepción, Chile.

Mitchell, G., N. Jones, and T. Coutinho. 2005. Alternatives to benomyl fungicide in controlling Fusarium circinatum: results from in vitro studies. Forest Shaw Research Centre, SAPPI. Document 3. p. 1-14.

Molina, G., S. Zaldúa, G. González, y E. Sanfuentes. 2006. Selección de hongos antagonistas para el control biológico de Botrytis cinerea en viveros forestales en Chile. Bosque 27(2):126-134.

Papavizas, G. 1985. Trichoderma and Gliocladium: biology, ecology, and potential for biological control. Annual Review of Phytopathology 23:23-54.

Paulitz, T.C., C.S. Park, and R. Baker. 1987. Biological control of Fusarium wilt of cucumber with nonpathogenic isolates of Fusarium oxysporum. Canadian Journal of Microbiology 33:349353.

Postma, J., and H. Rattink. 1992. Biological control of Fusarium wilt of carnation with a non-pathogenic isolate of Fusarium oxysporum. Canadian Journal of Botany 70:1199-1205.

Quesada, T., V. Gopal, P. Cumbie, A. Eckert, J. Wegrzyn, D. Neale, et al.2010. Association mapping of quantitative disease resistance in a natural population of loblolly pine (Pinus taeda L.). Genetics 186:677-686.

Rotella, A. 2005. Manejo del hongo Fusarium circinatum en viveros forestales. In Resúmenes de la XX Silvotecna: Sanidad forestal en un mundo globalizado. Sesión No 12. 7-8 November 2005. CORMA Bío Bío, Concepción, Chile.

SAS Institute. 2000. User's guide statistic. Version 8.1. 646 p. SAS Institute, Cary, North Carolina, USA.

Schweigkofler, W., K. O`Donnell, and M. Garbelotto. 2004. Detection and quantification of airborne conidia of Fusarium circinatum, the causal agent of pine pitch canker, from two California sites by using a real-time PCR approach combined with a simple spore trapping method. Applied and Environmental Microbiology 70:3512-3520.

Silva, J., and W. Bettiol. 2005. Potencial of non-pathogenic Fusarium oxysporum isolates for control of Fusarium kilt of tomato. Fitopatologia Brasileira 30:409-412.

Storer, A.J., D.L. Wood, and T.R. Gordon. 2002. The epidemiology 
of pitch canker of Monterrey pine in California. Forest Science 48:694-700.

Sutton, J., D.W. Li, G. Peng, H. Yu, P. Zhang, and R. ValdebenitoSanhueza. 1997. Gliocladium roseum, a versatile adversary of Botrytis cinerea in crops. Plant Disease 81:316-328.

Sutton, J., W. Liu, R. Huang, and N. Owen-Going. 2002. Ability of Clonostachys rosea to establish and suppress sporulation potential of Botrytis cinerea in deleafed stems of hydroponic greenhouse tomatoes. Biocontrol Science and Technology 12:413-425.

TPCP. 2002. Fusarium circinatum in pine nurseries: A guide to appropriate management strategies. Tree Pathology Cooperative Programme (TPCP), University of Pretoria, Pretoria, South Africa. Available at http://www.fabinet.up.ac.za/tpcpweb/pamphlets/ fusarium.pdf (accessed 16 September 2009).

Vinale, F., K. Sivasithamparam, E. Ghisalberti, R. Marra, S. Woo, and M. Lorito. 2008. Trichoderma-plant-pathogen interactions. Soil Biology and Biochemistry 40:1-10.

Wikler, K., and T.R. Gordon. 2000. An initial assessment of genetic relationships among populations of Fusarium circinatum in different parts of the world. Canadian Journal of Botany 78:709717.

Wingfield, M.J., A. Hammerbacher, R.J. Ganley, E.T. Steenkamp, T.R. Gordon, B.D. Wingfield, and T.A. Coutinho. 2008. Pitch canker caused by Fusarium circinatum - a growing threat to pine plantations and forests worldwide. Australasian Plant Pathology 37:319-334.

Wingfield, M.J., A. Jacobs, T.A. Coutinho, R. Ahumada, and B.D. 2002. First report of the pitch canker fungus, Fusarium circinatum, on pines in Chile. Plant Pathology 51:397.

Yu, H., and J. Sutton. 1997. Morphological development and interactions of Gliocladium roseum and Botrytis cinerea in raspberry. Canadian Journal of Plant Pathology 19:237-246. 